\title{
弾塑性骨組の指定設計用変形指標に対する \\ 2 段階地震応答制約設計法 \\ DUAL CRITERIA DESIGN OF INELASTIC FRAMES \\ FOR SPECIFIED SEISMIC DESIGN DEFORMATION INDICES
}

\author{
中村 恒 善*, 小坂 郁夫** \\ Tsuneyoshi NAKAMURA and Ikuo KOSAKA
}

\begin{abstract}
An efficient method of dual criteria design of inelastic frames for specified seismic design strain and ductility is presented on the basis of the authors' method of seismic strain-constrained design of elastic frames. The latter enables one to find the set of bending stiffnesses of a frame such that the SRSS strain of every member with a specified depth due to a set of design spectrumcompatible earthquakes would be equal to a specified value.

Each frame designed for a set of specified smooth distribution of column-end strains and a set of specified uniform distribution of beam-end strains is shown to exhibit a fairly uniform distribution of storey ductility indices under Level 2 design earthquakes'. These characteristics are utilized conveniently in the method of dual criteria design of an inelastic frame for specified design strain and ductility.
\end{abstract}

Keywords : inelastic frame, strain constrained design, ductility constrained design, dual criteria design, earthquake-response constrained design

非弾性骨組，ひずみ制約設計，ダクティリティー制約設計，2 段階制約設計，地震応 答制約設計

\section{1. 序}

本論文では, 著者らの「平面骨組の地震応答ひずみ制

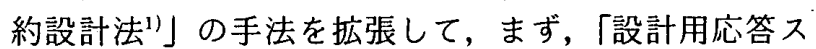
ペクトルに適合する激震動群に対する梁降伏型骨組の弾 塑性応答 (層塑性率) 制約設計法」を構成する。そのた めに,これまでの研究結果から塑性変形が指定層にほぼ 均等に分散する骨組群の設計手順と層塑性率予測法を示 す。この骨組群の地震応答解析結果からの設計手順の検 証とより詳細な応答予測式の提示も行う。つぎにこの 層塑性率予測法を利用した「2 段階の制約条件下の代表 建築骨組の設計方法」を提示する。ここで採用する 2 段 階制約条件下での設計問題は通常の建築骨組解析法の 「逆問題」である。設計解の誘導には, その基礎的逆問 題である「建築ラーメンの 1 次固有周期と 1 次ひずみ モード制御設計問題」の開形解韋を利用する。

著者の提示した文献 1）では，建築骨組の通常の設計 時において行われる 2 段階の耐震安全性の判定のうち,
耐用年数中に経験する可能性が高い地震動（レベル 1 地 震動）に対する有用な設計法を提示した。この手法を用 いればレベル 1 用応答スペクトル適合地震外乱に対し て, 全部材の代表要素応答ひずみの平均最大值が設計者 の指定した応答量となるように，骨組の全部材の曲げ剛 性を容易に選定することができる。設計された骨組は最 強地震動（レベル 2 地震動）に対しても安全であるかど うかのチェックを後に行う必要があるが, 各層ともほほ 同一のひずみの指定を行った場合には，この骨組はレベ ル 2 地震動に対して塑性変形が分散する挙動を呈するこ とも例示している。

これまでのレベル 2 地震動に対する塑性応答制約設計 法のうち，せん断型構造物モデルについては各種の手 法3)が提示されており，著者らも設計法 ${ }^{41,5)}$ の提示を行っ ている。本論文で対象とするような梁と柱で構成された 骨組を対象とした塑性応答制約設計法としては,例えば, 以下のような研究がある。
* 京都大学工学部建築学科 教授 $\cdot$ 工博, $\mathrm{Ph} . \mathrm{D}$

** 京都工芸織維大学工芸学部造形工学科 助手' 工修
Prof., Dept. of Architecture, Faculty of Engineering, Kyoto Univ., Dr. Eng., Ph. D

Research Assoc., Dept. of Architecture and Design, Faculty of Engineering and Design, Kyoto Institute of Technology, M. Eng. 
等価線形化手法を用いた方法としては, 石丸 ${ }^{6)}$, 藤原 と秋元 ${ }^{7}$ の研究がある。石丸は, 非弾性応答スペクトル 法と確定論的等価線形化手法を組み合わせて, 指定した 部材塑性率が各梁に生じるような梁降伏型骨組の梁の降 伏モーメントを求める方法を提示している。この場合に は部材剛性を降伏モーメントとは別個に取り扱ってお り, 部材断面の決定のための操作を必要とする。藤原と 秋元は, 定常ランダム過程に従う外乱に対して, 梁降伏 型骨組に確立論的等価線形化法を適用し，信頼性制約条 件下で部材の剛性和を最小化する問題に対する解を数值 的に見いだす方法を提案している。この場合には, 崩壊 確率を大きくすると解が収束しない場合がある。

また, 秋山ら ${ }^{81}$ は, 実地震波の下で塑性率がほぼ均等 に分散するせん断型構造物モデルの降伏せん断力係数分 布 (強度分布) を多数の解析結果から選定し,この降伏 せん断力係数分布からはずれた場合の塑性変形の集中度 合いとその大きさを予測する式を提示した。これらの結 果を骨組などに適用する方法を提示している。この場合 には, 種々な形式の構造物や地震外乱に適用範囲を広げ ているため, その時々の対象骨組形状や地震外乱などの 設計条件により応答制御の精度が異なる可能性がある。

骨組の部材剛性を直接与える閉形解を提示した研究も 行われている。本論文著者の中村と竹脇 ") $は$, 設計用静 的荷重に対する非線形弾性骨組のシステム性能制約下の 最適解の閉形表現を導き, レベル 2 地震時の層せん断力 をレベル 1 地震時の層せん断力から近似評価することに より梁の塑性率および柱の応答制約条件を満たす骨組の 各部材の㴊性およびそれに対応する強度を求める方法を 提案している。また, 時刻歴応答解析によりその精度を 検証している。この場合は設計用静的荷重の設定方法に よって精度が異なる可能性がある。

これまでの手法に対して, 本論文の設計手法は以下の ような特徴を有している。

（1）「文献 1) で提案済みである弾性ひずみ制約設計 法」に基づく弾塑性応答制約設計法の提示である。そこ では設計用応答スペクトルに適合するレベル 2 設計用地 震動群下での指定層の層塑性率の平均最大値を同一の指 定値とする設計理論を展開する。弾性応答時のひずみま でも制約する理論に基づいているので, 本論文の対象と する範囲 (層塑性率が 2.0 程度以下の範囲) ではきわめ て精度が良い。

（2）「1次固有周期および 1 次ひずみモード制御設計 骨組の閉形解」を利用しているので, 数回の収束計算で 設計解が容易に求まる。

（3）代表骨組モデルとして均等スパン骨組から取り出 した梁降伏魚骨型モデルを採用するが，理論展開の基礎 となっている弾性設計理論は任意の層数, 部材長, 質量 分布の骨組にも適用可能であるので, 本論の理論展開お
よび応答量関係式などの誘導手順の考え方は，これらの 骨組にも適用可能であると期待される。

（4）骨組の個々の部材の㴊性と強度を同時に取り扱 い，部材断面まで直接的に求めることができる理論を展 開している。ここで得られる骨組の部材剛性や強度は, 非線形性のレベルが層塑性率で 2 程度である骨組の整合 剛性, 強度の標準値としての意義を有している。設計解 は多スパン骨組の内側梁，柱の初期設計として直接使用 することもできる。

（5）これまでの設計法がレベル 1 またはレベル 2 地震 動のいずれか一方に対する設計法を提示しているのに対 して，本論文では両方の地震動を対象とした 2 段階制約 条件下での設計解の誘導手法を提示している。

\section{2 段階制約設計問題}

\section{1 設計用地震動と設計対象骨組形状}

〔設計用地震動〕

現実の高層骨組の設計には設計用地震動として記録地 震波や人工地震波などが安全性の検定のために用いられ る。その際, 過去の代表的な記録地震波, 地域特性を考 愿に入れた地震波，長周期成分を多く含んだ地震波など が採用される。他方では，設計用地震動の特性や大きさ を表すのに応答スペクトルが採用されることが多い。

本論文では，基本的な論理を構成する第一ステップと して，また，設計資料としての標準剛性や強度を得るこ とを目的として，2 個のレベルの設計用速度応答スペク トル $S_{v}^{(1)}, S_{v}^{(2)}$ に適合する地震動群を採用する。

\section{[設計用地震動]}

以下に示す応答スペクトルに適合する地震動群を設 計用地震動とする。

(レベル 1 地震動の速度, 変位応答スペクトル)

$$
\begin{aligned}
& S_{v}^{(1)}=\hat{S}_{v}^{(1)}(T ; h) \cdots \cdots \cdots \cdots \\
& S_{D}^{(1)}=(T / 2 \pi) \hat{S}_{v}^{(1)}(T ; h) .
\end{aligned}
$$

(レベル 2 地震動の速度, 変位応答スペクトル)

$$
\begin{aligned}
& S_{V}^{(2)}=\hat{S}_{V}^{(2)}(T ; h) \cdots \ldots \ldots . . . \\
& S_{D}^{(2)}=(T / 2 \pi) \hat{S}_{V}^{(2)}(T ; h)
\end{aligned}
$$

ここで, $\hat{S}_{v}^{(1)}(T ; h), \hat{S}_{v}^{(2)}(T ; h)$ は指定值である。 $T$ は固有周期， $h$ は減衰定数である。なお，変位応 答スペクトルは（2）（4）式のように速度応答スペ クトルから求まるとする。

なお，レベル 1 とレベル 2 の応答スペクトルはそれぞ れ独立に設定される場合とレベル 2 の応答スペクトルが レベル 1 の定数倍として設定される場合がある。5 章で はそれぞれの場合についての設計法を提示する。

[設計対象骨組形状]

設計法誘導の考え方が最も分かりやすいように，設計 対象骨組形状として以下の代表骨組モデルを採用する。 

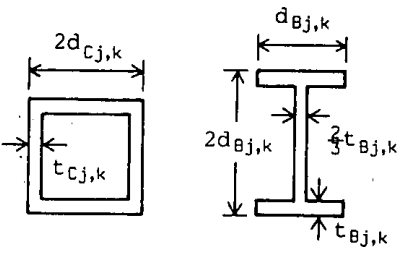

図一1 部材断面形状

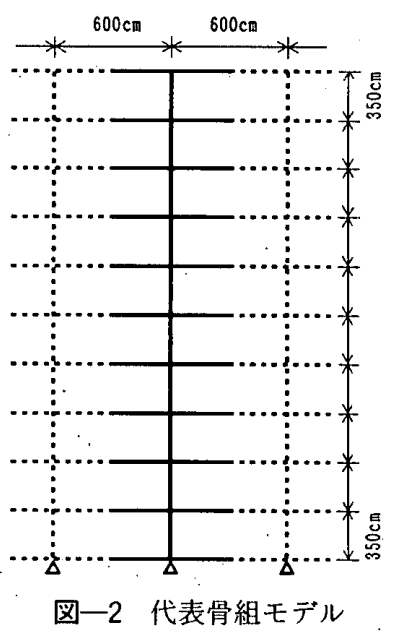

〔代表骨組モデル〕

$\mathrm{H}$ 形断面梁と箱型断面柱（図一1）で構成された魚 骨型モデル（図一2）を代表骨組モデルとする。なお， スパン長 $l_{k}$, 階高 $h_{j}$, 節点集中質量 $m_{j}$, 部材せい $d_{c j, k}, d_{b j, k}$, 材料の弾性係数 $E$ ，降伏ひずみ $\varepsilon_{y}$ はあ らかじめ設定されるものとする。 $j, k$ は第 $j$ 層, 第 kスパンを表す。

このモデルは，多層多スパン骨組の内側梁，柱に対応 するモデルである。4 章においては，スパン長，階高が 同じで，5，10，15 層の 3 種類の層数の代表骨組モデル を採用するが，本論の設計法の考え方は層数にかかわら ず適用可能である。また，断面形状がほぼ相似形に近い 部材では弾性時および弾塑性時の復元力特性も曲げモー メントー曲率平面上では相似形に近い形状となることを 考慮すると，4章で得られる応答予測式はさまざまな部 材中心線形状や質量分布の骨組にもほぼそのまま適用で きると思われる。

なお，本論文では，文献 1) と同様に，伸びなし変形 の仮定に基づいた理論を構成する。部材せいや材料の弾 性係数，降伏ひずみをあらかじめ設定するので，部材剛 性が求まれば部材の断面寸法や強度も求まる。

2.22 段階制約のための設計クライテリア 〔設計クライテリア〕

多くの場合, 設計用外乱下での各種の応答量のうち, 設計者が指定した応答量が指定值以内となることが設計 のクライテリアとされる。レベル 1 設計用地震動に対す る安全性の検定においては, 許容応力度型検定式が用い られるが，ここでは各部材の代表要素の平均最大応答ひ
ずみを骨組の安全性の主要な指標とする。レベル 2 設計 用地震動に対する骨組の安全性の指標には層塑性率が採 用されることが多い。本論文も層塑性率を採用する。

「定義 1」(設計クライテリア 1)

レベル 1 設計用地震動群下での各部材の最大材端縁 ひずみの期待值が指定値となる。 (梁ひずみの期待值)

$$
\bar{\varepsilon}_{b i(\max )}^{(1)}=\hat{\varepsilon}_{b i}^{(1)} \quad(i=1 \sim g)
$$

(柱ひずみの期待値)

$$
\vec{\varepsilon}_{c u \max )}^{(1)}=\hat{\varepsilon}_{c i}^{(1)} \quad(i=1 \sim n)
$$

ここで， $g, n$ はそれぞれ梁，柱の部材数。下添字の $i$ は $i$ 番目の部材を, 上添字の（1）はレベル 1 地震 を, 一は期待値, ‘は指定値を表す。

レベル 2 地震外乱に対する一般の骨組の挙動として は, 塑性変形が特定の層に集中せず, 指定層群に均等に 分散する挙動が望ましい場合が多い。

「定義 2」(設計クライテリア 2)

レベル 2 設計用地震動群下で, 梁降伏型骨組（指定 された中層部の梁にのみ塑性変形が生じ，柱は弾性域 に留まる骨組）となり, かつ, 塑性変形を含む層の層 間塑性率の期待值が同一の指定值となる。

(柱ひずみの期待值)

$$
\bar{\varepsilon}_{c u \max )}^{(2)}<\varepsilon_{y} \quad(i=1-n) .
$$

(指定層以外の梁ひずみの期待値)

$\bar{\varepsilon}_{B i(\max )}^{(2)}<\varepsilon_{y} \quad$ (指定層以外)

(層塑性率の期待值)

$$
\bar{\mu}_{j}=\hat{\mu} \quad \text { （指定層） }
$$

ここで, $n$ は柱の部材数, 下添字の $i$ は $i$ 番目の部 材層を, $j$ は $j$ 番目の層を, 上添字の $(2)$ はレベル 2 地震動を, 一は期待值, ‘は指定值を表す。

$\varepsilon_{y}$ は降伏ひずみ值である。

〔クライテリア適合と許容〕

設計用地震動としてスペクトル適合地震動群を採用し た場合には, 地震動群の中の個々の地震動に対して応答 量は分散する。地震動群に対する平均最大応答值を設計 クライテリアに採用する場合, 応答量の分散が大きい場 合にはその設計クライテリアは必ずしも設計者にとって 有用とはならない。また, 多数の地震動群の中から限定 された個数の地震動を対象とするため, 期待值 (平均最 大応答値) がちょうど指定值になるよう設計条件を設定 するよりも指定された範囲内に収まるという条件を設定 する方が現実的である。これらの理由により, 以下のよ うなクライテリアに関する定義を設定する。

「定義 $3 」$ ( クライテリア適合)

上記の設計クライテリアの内で，符号で指定された 条件に対して, 最大応答值の期待値が以下の条件を満 
足する場合，設計骨組はクライテリアに適合するとい う。

地震動群に対する平均最大応答値 $M$ (最大応答値 の期待値）が指定值 $\hat{M}$ の近傍 $\{\hat{M}(1 \pm \Delta)\} に 入 り$, 最 大応答値の標準偏差 $\sigma$ が設計者の設定値 $\hat{\sigma}$ 以下とな る。

$\hat{M}(1+\Delta) \geqq \hat{M} \geqq M(1-\Delta)$

$\sigma \leqq \hat{\sigma}$ (7-b)

「定義 4」(クライテリア許容)

上記の設計クライテリアの内で，符号で指定された 条件に対して, 最大応答值の期待值が以下の条件を満 足する場合, 設計骨組はクライテリアに許容であると いう。

地震動群に対する平均最大応答値 $M$ (最大応答値 の期待値）が指定值 $\hat{M}(1+\Delta)$ 以下となり, 最大応答 値の標準偏差 $\sigma$ が設計者の設定値 $\hat{\sigma}$ 以下となる。

$$
\begin{aligned}
& M \leqq \hat{M}(1+\Delta) \\
& \sigma \leqq \hat{\sigma} \cdots \cdots \cdots \cdots
\end{aligned}
$$

地震動群に対する全部材の材端縁ひずみの平均最大応 答值 $\bar{\varepsilon}_{\ell(\max )}^{(1)}$ が $(5-\mathrm{a}, \mathrm{b})$ 式の指定值に対して $(7-\mathrm{a}, \mathrm{b})$ 式の条件を満足する骨組をクライテリア 1 適合骨組とい い，(8-a，b) 式の条件を満足する骨組をクライテリア 1 許容骨組という。

文献 1）の「平面建築骨組の指定設計ひずみに対する 地震応答制約設計法」を用い設計した骨組の人工地震動 群下での最大ひずみ応答量の期待値は指定値の近傍にあ り，標準偏差も小さいことが例証されている1!。このこ とから,クライテリア1適合骨組を文献1）の手法で設 計できることがかかる。設計法の概要は 3 章で述べる。

層塑性率については地震動群に対する全層の平均 $\mu_{a v}$ が (6-c) 式の指定值に対して (7-a, b) 式の条件を満 足する骨組をクライテリア 2 適合骨組といい，(8-a, b) 式の条件を満足する骨組をクライテリア2 許容骨組とい う。クライテリア 2 適合骨組の設計法は 3 章, 5 章にお いて述べる。

\section{3 均等塑性率骨組と設計問題}

[均等塑性率骨組]

2 段階の制約条件下での設計においては, レベル 1 地 震動群とレベル 2 地震動群の応答スペクトルの性質やレ ベルの設定の差異により，દ゙のクライテリアに許容また は適合となる骨組が設計可能であるかが巽なる。一方の クライテリアに適合し, 他方のクライテリアに許容とな る骨組が必ずしも存在するとは限らない。

本論では，以下のような均等塑性率骨組群を設定する ことにより 2 段階制約設計問題を述べる。

\section{[均等塑性率骨組]}

代表骨組モデルで, レベル 2 地震動群に対して, 梁 降伏型挙動をし，かつ，指定層の最大層塑性率の期待 値が一定値の $\Delta$ 近傍に入る骨組を均等塑性率骨組と 呼ぶ。均等塑性率骨組の集合を均等塑性率骨組群と呼 ぶ。

この均等塑性率骨組は, レベル 2 地震動群に対する骨 組の挙動として塑性変形が多数の層に少ない偏りで分散 する挙動が望ましい場合が多いことを考慮して設定した ものである。

\section{〔 2 段階制約設計問題〕}

層塑性率が指定された場合のクライテリア 2 適合骨組 は均等塑性率骨組群の 1 要素であるが，レベル 1 地震動 群の設定が特別である場合を除いて一般にはクライテリ ア1適合骨組は均等塑性率骨組群には含まれない。この ことを考虑すると設計問題は以下のように述べられる。

\section{[2 段階制約設計問題}

指定されたレベル 1,2 の設計用地震動群の下で, クライテリア 1,2 に対して以下のいずれかの設計条 件を満足する均等塑性率骨組の部材曲げ剛性とそれに 対応する断面サイズを求めよ。 (設計条件)

(1) クライテリア 2 に適合し,クライテリア1に許 容となる(クライテリア 2 が活動的)。

(2) 両方のクライテリアに許容であり, かつ, レ ベル 1 地震外乱下で 1 個以上の部材の最大ひずみの期 待值がクライテリア 1 の指定值の $\Delta$ 近傍に入る (ク ライテリア 1 が活動的)。

\section{3. 均等塑性率骨組の設計法とその応答予測式}

3.1 骨組の弾性応答量と弾塑性応答量の関係

これまでの研究により以下の事実が明らかにされてい る。

\section{〔多質点並進せん断型モデル〕}

各層の塑性率が 2.0 程度以下で全層がほぼ同じ塑性率 を呈する多質点並進せん断型弾塑性モデルの最大変位お よび風間相対変位は, 弾性時剛性が同じ多質点せん断型 弾性モデルの応答量とほぼ同じか若干小さな値となるこ とを著者は文献 4)，5）において提示している。

〔骨組モデル〕

レベル 2 用応答スペクトルと相似なレベル 1 設計用応 答スペクトルに適合する外乱群の下で中層部の梁に生じ るひずみの值が一定となり, 他の部材はそれより十分小 さなひずみとなるよう弾性設計された代表骨組モデル は, レベル 2 外乱下で中層部の平均最大塑性率が一様と なる梁降伏型挙動を呈す。その骨組のレベル 1, 2 外乱 下での平均最大層間相対変位の大きさは弾性挙動と弾塑 性挙動にかかわらず, 応答スペクトルの大きさにほぼ比 
例することが例証されている゙。

上記の,「世ん断型モ.デルの層間相対変位は弾性時剛 性が同じモデルの応答量とほぼ同じか若干小さな值とな ること」，および，「骨組モデルの平均最大層間相対変位 の大きさは弾性挙動之弾塑性挙動にかかわらず応答スペ クトルの大きさにほぼ比例する」という事柄は, 以下の ことを示している。レベル 1 地震動がレベル 2 地震動の $1 / 2$ の大きさの場合には, レベル 1 地震動下での最大応 答值がちょうど弾性限の值となるような余裕率の小さな 骨組でも，塑性変形を中層部に一様に分布させることに よってレベル 2 地震動下での塑性率を 2.0 程度以下にす ることができる。

\section{2 弾性骨組のひずみ制約設計法1)}

以上の成果に基づいて，「弾性骨組のひずみ制約設計 法に基づく均等塑性率骨組」の作成手順を示すが，ここ では，まず，弾性骨組のひずみ制御設計法”の概要を要 約する。

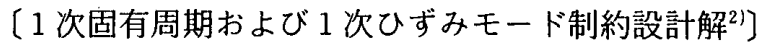

1 次固有值の指定値を

$$
\Omega_{1}=\Omega_{a} \quad\left(\Omega_{a}: \text { 指定值 }\right)
$$

とし，1次のひずみモードを

$$
\varepsilon_{B j, \kappa}^{L} /\left(\alpha_{J} / \hat{\lambda}_{B j, k}\right)=\varepsilon_{B j, \kappa}^{R} /\left(\alpha_{j} / \hat{\lambda}_{B j, k}\right)=\varepsilon_{C J, k}^{L} /\left(\beta_{j} / \hat{\lambda}_{C j, k}\right)
$$

ここで,， $\alpha_{j}, \beta_{j}$ はひずみモードを指定する ために設計者が与える係数であり, $\hat{\lambda} は($ 部 材長/せい）比である。

と指定した時の代表骨組モデルの部材曲げ剛性は次式の ように求まる。

(柱曲げ剛性)

$$
J_{j, k}=\frac{-6 h_{j}^{2}}{4\left(\alpha_{j}-\alpha_{j-1}-6 \beta_{j}\right)} \Omega_{a} \sum_{n=j}^{f}\left(m_{n} \sum_{i=1}^{n} R_{i} h_{i}\right) \cdots
$$

(梁曲げ剛性)

$$
\begin{aligned}
K_{j, k}= & \frac{\left(\alpha_{j}-\alpha_{j-1}-3 \beta_{j}\right) l_{k} h_{j}}{4 \alpha_{j}\left(\alpha_{j}-\alpha_{j-1}-6 \beta_{j}\right)} \Omega_{a} \sum_{n=j}^{f}\left(m_{n} \sum_{i=1}^{n} R_{i} h_{i}\right) \\
& -\frac{3 \beta_{j+1} l_{k} h_{j+1}}{4 \alpha_{j}\left(\alpha_{j+1}-\alpha_{j}-6 \beta_{j+1}\right)} \Omega_{a} \sum_{n=j+1}^{j}\left(m_{n} \sum_{i=1}^{n} R_{i} h_{i}\right)
\end{aligned}
$$

ここで, $R_{i}=\left(2 \alpha_{i-1} / 9+\alpha_{i} / 9+\beta_{i} / 3\right)$ である。

〔材端縁ひずみのSRSS 応答評価式〕

設計用応答スペクトル適合地震動下での全部材の弾性 応答最大ひずみの期待値を 2 乗和平方根法 (SRSS 法) を用いて評価する。

$$
\begin{aligned}
& \left(\varepsilon_{B j, k \max }^{L}\right)^{2}=\sum_{i=1}^{f}\left(\nu^{(i)} S_{D}^{(i)} \varepsilon_{B j, k}^{L(i)}\right)^{2} \\
& \left(\varepsilon_{B j, k \max }^{R}\right)^{2}=\sum_{i=1}^{f}\left(\nu^{(i)} S_{D}^{(i)} \varepsilon_{B j, k}^{R(i)}\right)^{2} \\
& \left(\varepsilon_{B j, k \text { max }}^{U}\right)^{2}=\sum_{i=1}^{f}\left(\nu^{(i)} S_{D}^{(i)} \varepsilon_{C j, k}^{(U)}\right)^{2}
\end{aligned}
$$

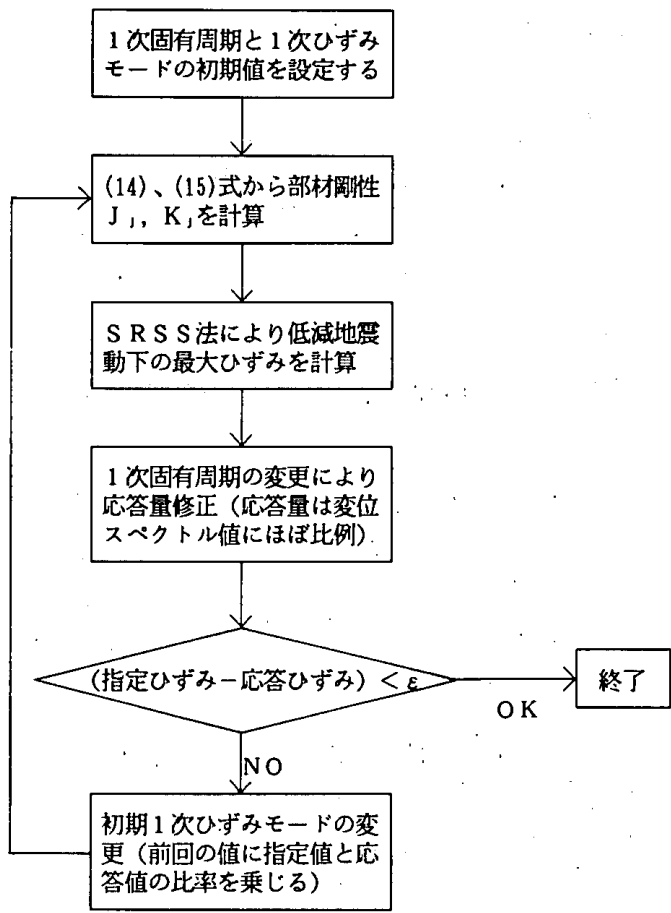

図一3 弾性骨組のひすみ制御設計手順

$$
\left(\varepsilon_{c s, k \max )}^{L}\right)^{2}=\sum_{i=1}^{f}\left(\nu^{(i)} S_{D}^{(i)} \varepsilon_{C j, k}^{L(i)}\right)^{2}
$$

ここで， $\nu^{(i)}$ は $i$ 次の刺激係数を， $S_{D}^{(i)}$ は $i$ 次の固有周期 と $i$ 次の減衰定数に対応する変位応答スペクトル值を表 し， $\varepsilon_{B j, k}^{\mu l)}$ などは固有ベクトルに対応するひずみ成分を表 す。

〔設計用地震動下でのひずみ制約設計手順〕

「設計用応答スペクトル適合地震動に対する全部材の 弾性応答最大ひずみ期待値がそれぞれ各部材ごとの指定 值と一致するように各部材サイズを設計する手順」は， 文献1）により，図一3のように要約できる。この方法 を簡単のため, 以下では「弾性骨組のひずみ制約設計法」 と称する。

\section{3 均等塑性率骨組の設定法}

ッ以上の研究結果に基づいて，2 章で述べた「均等塑性 率骨組」の設定を行う。

〔レベル 2 地震動に対する弾性限レベル地震動と骨組余 裕率]

弾性骨組のひずみ制約設計法!!を利用して弾塑性骨組 の部材剛性の選定を行うために，以下のような強震外乱 を設定し，レベル 2 地震動に対する骨組の強度を規定す るパラメータとして「レベル 2 骨組余裕率」を定義する。

\section{[弾性限レベル地震動]}

レベル 2 用応答スペクトルの $\tau_{y}$ 倍 $\left(\tau_{r} \leqq 1.0\right)$ のレ ベルで，形状が相似な応答スペクトル（低減スペクト ル）に適合する地震動の下で，一個の骨組の各部の最 大ひずみ期待値の内の最大值が弾性限ひずみ $\varepsilon_{y} に 一$ 致するとき，この低減スペクトルに適合する地震動を 「弾性限レベル地震動」という。 
[レベル 2 骨組余裕率)

骨組の強度パラメータを「レベル 2 骨組余裕率」と 呼び，1 個の骨組について 1 個定まる係数 $\tau_{y}$ の值を 「レベル 2 骨組余裕率」の大きさとする。

この弾性限レベル地震動に対して以下に示す指定ひず み分布の下で弾性設計を行うことにより均等塑性率骨組 群の近似解を求める。

〔均等塑性率骨組の弾性限レベル地震動下でのひずみ分 布]

レベル 2 骨組余裕率が同じ値となる骨組は多数存在す るが, 弾性限レベル地震動下での骨組各部の最大ひずみ の期待値の分布形状が指定されると 1 個の「レベル 2 骨 組余裕率」に対して 1 個の「骨組」が対応することにな る。

弾性限レベル地震動群に対する骨組各部の最大ひずみ 期待値分布の形状を以下のように指定した骨組群を採用 する。これは，均等塑性率骨組を設計するための指定法 である。

[弾性限レベル地震動下でのひずみ分布]

（1）指定層（中層部）の梁の最大ひずみの期待値を 以下とする。

$$
\bar{\varepsilon}_{b i \max )}^{(L)}=\varepsilon_{y}
$$

（2）その他の梁および全柱の最大ひずみの期待値を 以下とする。

$$
\begin{aligned}
& \bar{\varepsilon}_{b i \max )}^{(\lfloor)}=\hat{\varepsilon}_{b i}^{(L)} \\
& \bar{\varepsilon}_{c i \text { max }}^{(L)}=\hat{\varepsilon}_{c i}^{(L)}
\end{aligned}
$$

ここで，下添字の $i$ は $i$ 番目の部材を，上添字の (L) は弾性限レベル地震動を, 一 は期待値, “は指定 值を表す。(17-b)，(17-c）式の右辺の指定値は弹性 限ひずみ $\varepsilon_{y}$ より十分小さな值とする。

上記の指定法により作成される骨組は，レベル 2 地震 動の下で以下のような挙動を呈すると期待される。 （1）レベル 2 骨組余裕率が 1.0 以下の骨組では，弾性 限レベル地震動下でのひずみ指定值が大きい部材ほどレ ベル 2 地震動に対しては塑性化しやすいと考えられる。 この骨組はレベル 2 地震動に対して梁降伏型の挙動を示 し，塑性変形が指定層の梁にほぼ均等に分散すると期待 される。

（2）塑性変形を分散させることができれば，塑性変形 が特定の少数の部材に集中しないため, 個々の部材の塑 性変形量に大きな偏りは生じない。また，レベル 2 地震 動下の塑性変形量の大きさを評価する指標として層塑性 率を採用すると，塑性率も指定層にほぼ均等に分散する 可能性が高い。

\section{4 均等塑性率骨組の応答予測式}

均等塑性率骨組のレベル 2 骨組余裕率が 0.5 の場合に は, レベル 2 地震動のちょうど $1 / 2$ の地震動に対して弾
性限の最大応力量を示すことになる。レベル 2 地震動の $1 / 2$ 倍程度の大きさのレベル 1 地震動に対して弾性設計 をする場合が多いことを考慮して，レベル 2 骨組余裕率 が 0.5 以上の範囲の骨組を採用する。また，レベル 2 骨 組余裕率が 1.0 以上の骨組はレベル 2 地震動に対しても 弾性応答するので，以下ではレベル 2 骨組余裕率が 0.5 から 1.0 の実用的な範囲の骨組を対象とする。

均等塑性率骨組のレベル 2 骨組余裕率が 0.5 から 1.0 の骨組では，層塑性率は 2.0 以下程度となり，骨組の挙 動は弾性挙動に近いと考えられる。そのため, レベル 2 設計用地震動群下での層間相対変位は弾性限レベル地震 動下での弾性層間相対変位の $1 / \tau_{\mathrm{r}}$ 倍に近いか, または, それ以下で $\tau_{Y}$ の関数値となると思われる。層塑性率の 経験式は後に示すが，ここでは予測式としては以下の (18)，(19）式を採用する。

\section{〔層塑性率予測式 1]}

$$
\bar{\mu}=1 / \tau_{\mathrm{r}}
$$

〔層塑性率予測式 2]

$$
\bar{\mu}=f\left(\tau_{\mathrm{y}}\right)
$$

ここで， $f\left(\tau_{Y}\right)$ は $\tau_{Y}$ の関数で，通常は（18）式の右 辺より小さな值となる。

骨組形状が同じで部材断面形状がほぼ相似形の骨組群 を対象とする場合には，レベル 2 骨組余裕率と弾塑性応 答量との経験的な関係式 ((19) 式の右辺) を導くこと が可能である。4 章では，代表骨組モデルについての弾 塑性応答解析結果を示し, レベル 2 骨組余裕率と層塑性 率の関係式（層塑性率予測式 2) の例を示す。

上記の（18）式または（19）式から逆に層塑性率を指 定し, レベル 2 骨組余裕率を求めると設計者の指定する 層塑性率を呈する骨組を容易に設計できることがわか る。

\section{4. 均等塑性率骨組群の挙動検証}

\section{1 均等塑性率骨組群}

[レベル 2 設計用地震動]

ここでは, Newmark-Hall'10) の提示したデザインスペ クトルを採用する。レベル 2 地震動の地動加速度, 速度, 変位の最大値を以下とする。

（最大地動加速度） $402.0 \mathrm{~cm} / \mathrm{sec}^{2}$

（最大地動速度） $50.0 \mathrm{~cm} / \mathrm{sec}$

(最大地動変位)

$$
37.5 \mathrm{~cm}
$$

平均応答スペクトルの加速度, 速度, 変位の最大值は上 記の值に以下の倍率を乗じた值となる（文献 10）。

（加速度倍率） $3.21-0.68 \cdot \ln (100 \times h) \cdots(23)$

(速度倍率) $\quad 2.31-0.41 \cdot \ln (100 \times h) \cdots(24)$

(変位倍率) $\quad 1.82-0.27 \cdot \ln (100 \times h) \cdots(25)$

$h$ は減衰定数である。 


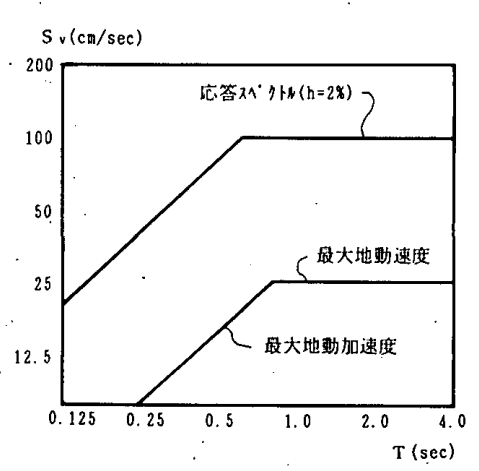

図-4 Newmark-Hall のデザインスペクトル

表一1 部材せい $(\mathrm{cm})$

\begin{tabular}{|c|c|c|c|c|c|c|c|c|c|c|c|}
\hline \multicolumn{3}{|c|}{$\begin{array}{l}\text { 設計 } 1-A \\
\left(\tau_{\mathrm{Y}}=0.96\right)\end{array}$} & \multicolumn{3}{|c|}{$\begin{array}{l}\text { 設計 } 1-B^{-B} \\
\left(\tau_{\mathrm{y}}=0.86\right)\end{array}$} & \multicolumn{3}{|c|}{$\begin{array}{l}\text { 設計 } 1-C \\
\left(\tau_{y}=0.75\right)\end{array}$} & \multicolumn{3}{|c|}{$\begin{array}{l}\text { 設計 } 1-D \\
\left(\tau_{\mathrm{r}}=0.67\right)\end{array}$} \\
\hline 層 & 梁 & 柱 & 層 & 梁 & 柱 & 層 & 梁 & 柱 & 層 & 梁 & 柱 \\
\hline 5 & 55 & 5 & & 53 & & & 50 & 50 & & 45 & 45 \\
\hline 4 & 65 & 55 & & 63 & 5 & 4 & 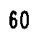 & 50 & & 55 & 45 \\
\hline 3 & 65 & 60 & & 63 & 5 & & 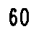 & & & 5 & 0 \\
\hline 2 & 70 & 04 & & 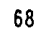 & & 2 & 65 & 6 & & 60 & 55 \\
\hline 1 & 70 & 60 & & .68 & 58 & 1 & 65 & 60 & & 60 & 55 \\
\hline 0 & 95 & & 0 & 93 & & 0 & 90 & & 0 & 85 & \\
\hline
\end{tabular}

\begin{tabular}{|c|c|c|c|c|c|c|c|c|c|c|c|}
\hline \multicolumn{3}{|c|}{$\begin{array}{l}\text { 設計 } 2-\mathrm{A} \\
\left(\tau_{\mathrm{Y}}=0,96\right)\end{array}$} & \multicolumn{3}{|c|}{$\begin{array}{l}\text { 設計 } 2-B \\
\left(\tau_{\mathrm{r}}=0.86\right)\end{array}$} & \multicolumn{3}{|c|}{$\begin{array}{l}\text { 設計 } 2-C \\
\left(\tau_{\mathrm{r}}=0.75\right)\end{array}$} & \multicolumn{3}{|c|}{$\begin{array}{l}\text { 設計 } 2-D \\
\left(\tau_{\mathrm{r}}=0.67\right)\end{array}$} \\
\hline 層 & 梁 & 柱 & 層 & 梁 & 柱 & 首 & 梁 & 柱 & 層 & 梁 & 柱 \\
\hline 10 & 63 & 68 & 10 & 60 & 65 & 10 & $4 !$ & 50 & 10 & 43 & 50 \\
\hline 9 & 73 & 68 & & & & 9 & & & & 53 & 50 \\
\hline 8 & 78 & 68 & & 7 & 65 & 8 & 60 & 50 & 8 & 58 & 50 \\
\hline 7 & 78 & 7 & 7 & 75 & & 7 & 60 & 5 & 7 & 58 & 55 \\
\hline 6 & 83 & 73 & 6 & 8 & 70 & 6 & 65 & 55 & 6 & 62 & 55 \\
\hline 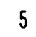 & 83 & 73 & 5 & 80 & 70 & 5 & 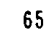 & & 5 & $6 ?$ & 55 \\
\hline 4 & 88 & 78 & 4 & 85 & 75 & 4 & 70 & 60 & 4 & 65 & 60 \\
\hline 3 & 88 & 78 & & 8 & 7 & & 70 & in & & 65 & 60 \\
\hline 2 & 88 & 78 & 2 & 85 & 75 & 2 & 70 & 60 & 2 & 65 & 60 \\
\hline 1 & 88 & 80 & & 85 & 75 & 1 & 70 & 60 & 1 & 65 & 60 \\
\hline 0 & 110 & & 0 & 110 & & 0 & 100 & & 0 & 95 & \\
\hline
\end{tabular}

\begin{tabular}{|c|c|c|c|c|c|c|c|c|c|c|c|}
\hline \multicolumn{3}{|c|}{$\begin{array}{l}\text { 設計 } 3-A \\
\left(\tau_{\mathrm{\gamma}}=0.96\right)\end{array}$} & \multicolumn{3}{|c|}{$\begin{array}{l}\text { 設計 } 3-B \\
\left(\tau_{\gamma}=0.86\right)\end{array}$} & \multicolumn{3}{|c|}{$\begin{array}{l}\text { 設計 } 3-C \\
\left(\tau_{\mathrm{y}}=0.75\right)\end{array}$} & \multicolumn{3}{|c|}{$\begin{array}{l}\text { 設計 } 3-D \\
\left(\tau_{\mathrm{r}}=0.67\right)\end{array}$} \\
\hline 層 & 梁 & 柱 & 層 & 梁 & 柱 & 層 & 梁 & 柱 & 層 & 梁 & 柱 \\
\hline 15 & 63 & 58 & 15 & 60 & 55 & 15 & 55 & 50 & 15 & 53 & 48 \\
\hline 14 & 68 & 63 & 14 & 65 & 60 & 14 & 60 & 55 & 14 & 58 & 53 \\
\hline 13 & 73 & 63 & 13 & 70 & 60 & 13 & 65 & 55 & 13 & 63 & 53 \\
\hline 12 & 73 & 63 & 12 & 70 & 60 & 12 & 65 & 55 & 12. & 63 & 53 \\
\hline 11 & 78 & 63 & 11 & 75 & 60 & 11 & 70 & 55 & 11 & 68 & 53 \\
\hline 10 & 78 & 68 & 10 & 75 & 65 & 10 & 70 & 60 & 10 & 68 & 58 \\
\hline 9 & 83 & 68 & 9 & 80 & 65 & 9 & 75 & 60 & 9 & 73 & 58 \\
\hline 8 & 83 & 68 & 8 & 80 & 65 & 8 & 75 & 60 & 8 & 73 & 58 \\
\hline 7 & 83 & 68 & 7 & 80 & 65 & 7 & 75 & 60 & 7 & 73 & 58 \\
\hline 6 & 83 & 73 & 6 & 80 & 70 & 6 & 75 & 65 & 6 & 73 & 63 \\
\hline 5 & 88 & 73 & 5 & 85 & 70 & 5 & 75 & 65 & 5 & 78 & 63 \\
\hline 4 & 88 & 73 & 4 & 85 & 70 & 4 & 80 & 65 & 4 & 78 & 63 \\
\hline 3 & 88 & 73 & 3 & 85 & 70 & 3 & 80 & 65 & 3 & 78 & 63 \\
\hline 2 & 88 & 73 & 2 & 85 & 70 & 2 & 80 & 65 & 2 & 78 & 63 \\
\hline 1 & 88 & 78 & 1 & 85 & 75 & 1 & 80 & 70 & 1 & 78 & 68 \\
\hline 0 & 110 & & 0 & 105 & & 0 & 95 & & 0 & 90 & \\
\hline
\end{tabular}

この值を用いてデザインスペクトルが定まる。減衰定 数を $2 \%$ とすると主要な部分の変位応答スペクトルは 以下となる（図一4）。

(変位応答スペクトル)

$$
\begin{aligned}
& S_{D 1}^{(2)}(T: 0.02)=27.88 T^{2} \quad(T \leqq 0.579) \cdots \cdots \cdot(26) \\
& S_{D 2}^{(2)}(T: 0.02)=16.12 T \quad(T \geqq 0.579) \cdots \cdots \cdots(27)
\end{aligned}
$$

表一2 低減地震動下の部材端縁ひずみ指定値 $\left(\times 10^{-4}\right)$

\begin{tabular}{|r|rl|}
\hline 層 & \multicolumn{1}{|c|}{ 梁 } & 柱 \\
\hline 5 & 7.1 & 7.1 \\
4 & 11.4 & 7.1 \\
3 & 11.4 & 7.1 \\
2 & 11.4 & 7.1 \\
1 & 11.4 & 7.1 \\
0 & 5.7 & \\
\hline
\end{tabular}

\begin{tabular}{|r|rc|}
\hline 層 & \multicolumn{1}{|c|}{ 梁 } & 柱 \\
\hline 10 & 7.1 & 7.1 \\
9 & 9.3 & 7.1 \\
8 & 11.4 & 7.1 \\
7 & 11.4 & 7.1 \\
6 & 11.4 & 7.1 \\
5 & 11.4 & 7.1 \\
4 & 11.4 & 7.1 \\
3 & 11.4 & 7.1 \\
2 & 11.4 & 7.1 \\
1 & 11.4 & 7.1 \\
0 & 5.7 & \\
\hline
\end{tabular}

\begin{tabular}{|r|rr|}
\hline 層 & \multicolumn{1}{|c|}{ 梁 } & \multicolumn{1}{l|}{ 柱 } \\
\hline 15 & 7.1 & 7.1 \\
14 & 9.3 & 7.1 \\
13 & 11.4 & 7.1 \\
12 & 11.4 & 7.1 \\
11 & 11.4 & 7.1 \\
10 & 11.4 & 7.1 \\
9 & 11.4 & 7.1 \\
8 & 11.4 & 7.1 \\
7 & 11.4 & 7.1 \\
6 & 11.4 & 7.1 \\
5 & 11.4 & 7.1 \\
4 & 11.4 & 7.1 \\
3 & 11.4 & 7.1 \\
2 & 11.4 & 7.1 \\
1 & 11.4 & 7.1 \\
0 & 5.7 & \\
\hline
\end{tabular}

\section{〔設計骨組〕}

骨組の層数は $5,10,15$ 層の 3 種類とし，階高は 3.5 $\mathrm{m}$, スパン長は $6.0 \mathrm{~m}$ とする。骨組の重量は 1 節点あた り 35 tonf とする。ヤング係数は $2100 \mathrm{t} / \mathrm{cm}^{2}$, 降伏応力 は $2.4 \mathrm{t} / \mathrm{cm}^{2}$ とする。設計骨組の娍衰定数は固有振動数 比例型とし，1 次モードの減衰定数を $2 \%$ とする。

レベル 2 骨組余裕率はそれぞれの層数について 0.67 , $0.75 ， 0.86,0.96$ の 種類とし, 合計 12 個の骨組を採 用した。

表一 1 に部材のせい, 表一 2 に弾性限レベル地震動下 でのひずみ指定值を示す。設計された骨組の断面 2 次 モーメント, 肉厚の 3 例を表一 3 に, 1 次固有周期を表 -4 に示す。

[時刻歴応答解析プログラムと解析モデル]

時刻歴解析プログラムには著者の提示した非定常履歴 単軸構成法則を用いた骨組の弾塑性応答解析プログラ ム11を用いた。これを用いることにより, 部材各部のひ ずみの応答量まで予測することができる。

解析骨組の要素分割は塑性域に入る可能性のある場所 では部材の長さ方向には $10 \mathrm{~cm}$ きざみ（要素長）とし， 断面は 14 分割した（図一5）。

\section{[レベル 2 人工地震動]}

レベル 2 地震動群には SIMQKE プログラム ${ }^{12)}$ を用い て作成した人工地震動の 10 波を採用した。設計用応答 スペクトルに適合する地震動に対する弾塑性応答の概略 が 3 章においてすでに明らかとなっている骨組群の，そ の設計用応答スペクトルに適合する地震動群に対する応 答量を得るという理想的な骨組, 地震動を対象とする場 合には外乱数は 10 波でも十分と考えられる。しかし， このことの検証のために，1 例（設計 3-C）については, さらに20波の地震動に対する応答解析を追加し, 本論 文で必要な応答量の分散が 10 波の地震動でも 30 波の地 震動でも大差ないことも確かめる。

減衰定数 $2 \%$ 時のターゲットとなる速度応答スペク トルと地震波の加速度一時刻平面上での包絡曲線を以下 
表-4 一次固有周期 $(\mathrm{sec})$

\begin{tabular}{|c|c|c|c|c|c|}
\hline \multicolumn{6}{|c|}{ 設計 $1-\mathrm{C}$} \\
\hline \multicolumn{3}{|c|}{$\begin{array}{r}\text { 断面 } 2 \text { 次モーメント } \\
\left(\begin{array}{lll}\mathrm{x} & 1 & 0^{5} \cdot \mathrm{cm}^{4}\end{array}\right)\end{array}$} & \multicolumn{3}{|c|}{ 部材肉厚 $(\mathrm{cm}$ ) } \\
\hline 屚 & 渠 & 柱 & 層 & 梁 & 柱 \\
\hline 5 & 0.67 & 1. 34 & 5 & 1.95 & 1.79 \\
\hline 4 & 1.20 & 2. 12 & 4 & 1.98 & 3.07 \\
\hline 3 & 1.79 & 3. 15 & 3 & 3.14 & 3.43 \\
\hline 2 & 2.45 & 3. 83 & 2 & 3. 37 & 3.12 \\
\hline 1 & 2.16 & 5.55 & 1 & 2.91 & 4. 95 \\
\hline 0 & 5. 20 & & 0 & 2.52 & \\
\hline
\end{tabular}

\begin{tabular}{|c|c|c|c|c|c|}
\hline \multicolumn{6}{|c|}{ 設詁 $3-$} \\
\hline \multicolumn{3}{|c|}{$\begin{array}{r}\text { 断面 } 2 \text { 次モーメント } \\
\left(\mathrm{x} 10^{\circ} \cdot \mathrm{cm}^{4}\right)\end{array}$} & \multicolumn{3}{|c|}{ 部材肉厚 $(\mathrm{cm}$ ) } \\
\hline 層 & 梁 & 柱 & 層 & 梁 & 柱 \\
\hline 15 & 0.45 & 0.82 & 15 & 0.92 & 1.04 \\
\hline 14 & 1.00 & 1. 59 & 14 & 1.63 & 1.5 \\
\hline 13 & 1.29 & 2.07 & 13 & 1.65 & 2.09 \\
\hline 12 & 1.66 & 2. 60 & 12 & 2.17 & 2.72 \\
\hline 11 & 2.19 & 2. 93 & 11 & 2.28 & 3.14 \\
\hline 10 & 2.43 & 3. 69 & 10 & 2.56 & 2.97 \\
\hline 9 & 2.97 & 3. 95 & 9 & 2.53 & 3.23 \\
\hline 8 & 3.21 & 4. 28 & 8 & 2.75 & 3.56 \\
\hline 7 & 3.46 & 4. 59 & 7 & 2. 99 & 3.88 \\
\hline 6 & 3.64 & 5.41 & 6 & 3.17 & 3.47 \\
\hline 5 & 4. 20 & 5.54 & 5 & 2.98 & 3.57 \\
\hline 4 & 4. 34 & 5.77 & 4 & 3.09 & 3.75 \\
\hline 3 & 4. 50 & 5.95 & 3 & 3.21 & 3.90 \\
\hline 2 & 4.62 & 6.07 & 2 & 3. 31 & 4.00 \\
\hline 1 & 3.98 & 8.59 & 1 & 2.80 & 4.58 \\
\hline 0 & 7.28 & & 0 & 3.04 & \\
\hline
\end{tabular}

\begin{tabular}{|c|c|c|c|}
\hline 設哖十 1-A & 㰻就 1-B & 設話十 1 - C & 設新 1 -D \\
\hline 0.46 & 0.49 & 0.54 & 0.62 \\
\hline 啜䑒 2-A & 䋁叶 2-B & 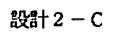 & 钤計 2-D \\
\hline 0.58 & 0.67 & 0.94 & 1. 09 \\
\hline 䋁影 3-A & 呚娄+3-B & 钤尌 $3-\mathrm{C}$ & 钤畧十3-D \\
\hline 0.88 & 1.02 & 1. 24 & 1.42 \\
\hline
\end{tabular}

\begin{tabular}{|c|c|c|c|c|c|}
\hline \multicolumn{6}{|c|}{ 設計 $2-c$} \\
\hline \multicolumn{3}{|c|}{$\begin{array}{r}\text { 断面 } 2 \text { 次モーメント } \\
\left(\begin{array}{lll}x & 1 & \left.0^{5} \cdot \mathrm{cm}^{4}\right)\end{array}\right.\end{array}$} & \multicolumn{3}{|c|}{ 部材肉厚 $(\mathrm{c} \mathrm{m})$} \\
\hline 層 & 梁 & 柱 & 層 & 梁 & 柱 \\
\hline 10 & 0.41 & 0.90 & 10 & 1.61 & 1.16 \\
\hline 9 & 1.05 & 1.64 & 9 & 2.32 & 2.25 \\
\hline 8 & 1. 35 & 2.13 & 8 & 2.27 & 3.09 \\
\hline 7 & 1.73 & 2. 96 & 7 & 3.02 & 3. 18 \\
\hline 6 & 2.31 & 3. 31 & 6 & 3. 14 & 3.65 \\
\hline 5 & 2.54 & 3. 80 & 5 & 3. 51 & 4. 36 \\
\hline 4 & 3.10 & 4. 38 & 4 & 3. 38 & 3.66 \\
\hline 3 & 3.29 & 4. 65 & 3 & 3.61 & 3.94 \\
\hline 2 & 3.46 & 4. 84 & 2 & 3.83 & 4. 14 \\
\hline 1 & 2.94 & 6.60 & 1 & 3.18 & 6.31 \\
\hline 0 & 6.88 & & 0 & 2. 40 & \\
\hline
\end{tabular}

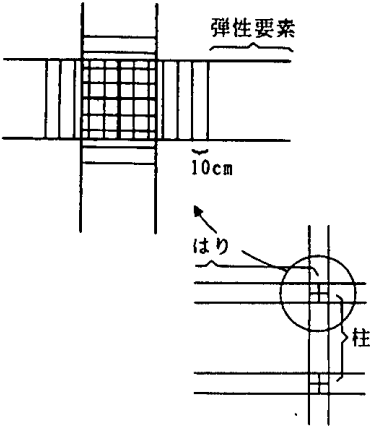

図一5 梁, 柱の要素分割

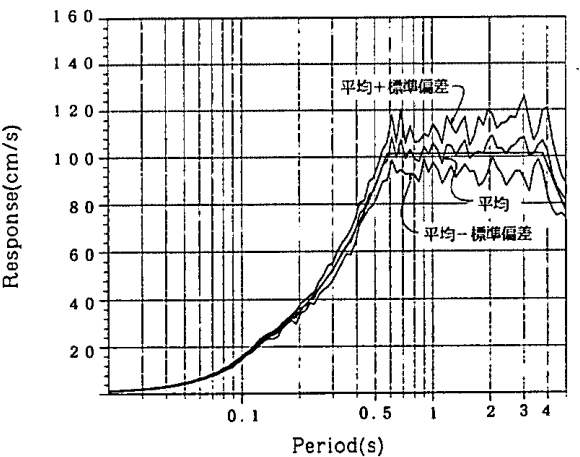

図一 6 人工地震外乱の速度応答スペクトル

$(0.03,1.92),(0.125,21.92),(0.579,101.5)$,

$(3.78,101.5),(5.0,76.82)$

(包絡関数)

包絡関数としては Jennings 型を採用した。

$$
\begin{array}{ll}
\zeta(t)=0.41 g \cdot(t / 3)^{3} & (0.0 \leqq t<3.0) \\
\zeta(t)=0.41 g & (3.0 \leqq t<12.5) \\
\zeta(t)=0.41 g \cdot \exp [-0.24(t-12.5)]
\end{array}
$$

ターゲットスペクトルと人工地震動 10 波の速度応答 スペクトルの平均値と標準偏差を図一6に示す。人工地 震動の速度応答スペクトルの分散は $10 \%$ 程度あり, 4 章ではこのことにより生じる応答量の分散をも含んだ結 果となっている。

\section{2 均等塑性率骨組群の挙動検証}

上記のように設計された均等塑性率骨組群の人工地震 動群下での弾塑性応答量の分布の特性を要約すると次の とおりである。特に, 最大応答量の 10 波の平均值（期 待值) とその $\pm \sigma$ (標準偏差) に着目してその結果を述 ベる。

\section{[弾性領域の進展]}

梁の塑性領域は今回の解析骨組のいずれの場合にも梁 の材端から $40 \mathrm{~cm}$ 以内に収まっている。また，レベル

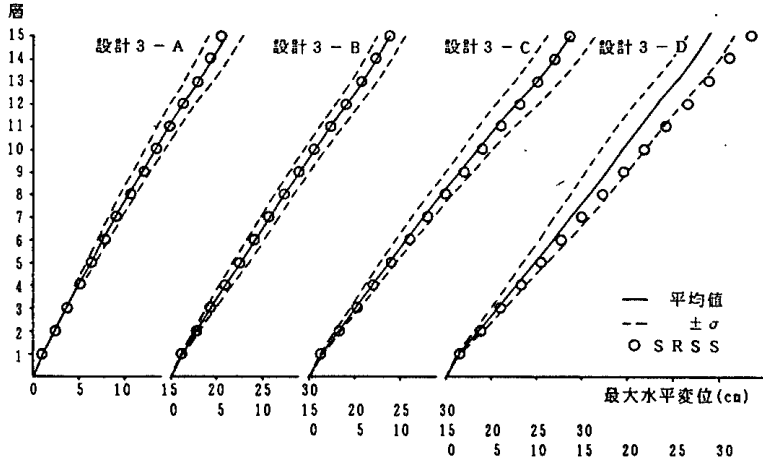

図一7 最大水平変位

2 骨組余裕率が $0.75 ， 0.67$ の設計 3,4 の $5,10,15$ 層 の骨組では, 10 個の地震動すべてに対して中間層の梁 の材端縁ひずみの最大值は降伏点を越えている。レベル 2 骨組余裕率が 0.86 の設計 2 の骨組でも 10 層の骨組の 1 個の地震動に対する例を除いて他の 29 例は中間層の 全梁の材端最大ひずみが降伏点を越えている。また，柱 は全骨組とも弾性範囲内に収まっている。このように， 梁降伏先行型骨組となることが検証された。 

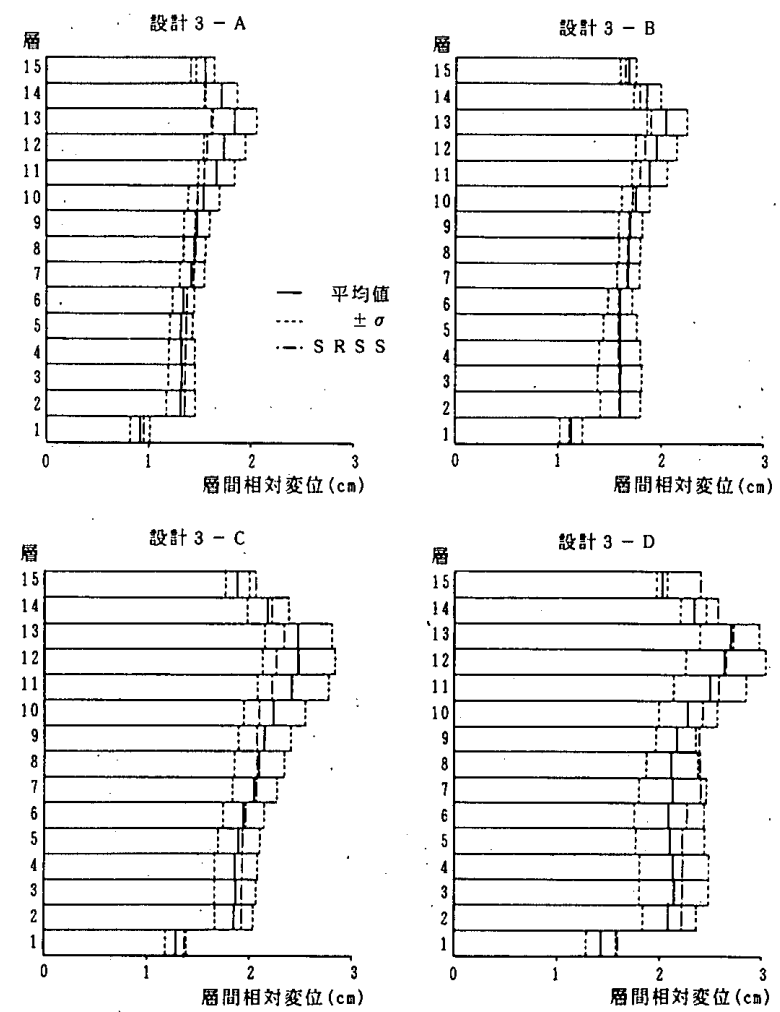

図一8 層間相対変位

[最大変位]

15 層骨組の最大変位の期待値の高さ方向の分布を図 一7に実線で示す。また, 図上に期待值士標準偏差を点 線で,「同じ部材剛性を持ち， $\varepsilon_{y}$ を超えるひずみが生じ ても弾性であるとした骨組のレベル 2 設計用地震動群下 での SRSS 法予測值」(弾性骨組としてのSRSS 法予 測值）を一点鎖線で示す。

（1）変動係数はレベル 2 骨組余裕率が小さい骨組ほど 大きいが，最上層に着目すると変動係数は $9 \%$ 程度以 下である。

（2）平均最大水平変位は弾性骨組としての SRSS 法 予測值より一般に小さい。最上層ではSRSS 法予測值 の $86 \%-102 \% の$ 範囲の応答を示した。

[最大層間相対変位]

１5層骨組の最大層間相対変位の期待值の高さ方向の 分布を図一 8 に実線で示す。また, 図上に平均值士標準 偏差を点線で, 弾性骨組としての SRSS 法予測値を一 点鎖線で示す。他の層数の骨組も同様の応答をする。

（1） 各層ごとの最大層間相対変位の平均值は弾性骨組 としての SRSS 法予測值 $15 \%$ の範囲内の応答を示し た。変動係数は $20 \%$ 以内である。

（2）レベル 2 骨組余裕率が小さいほよ゙, 平均最大層間 相対変位は弾性骨組としての SRSS 法予測値より小さ くなる傾向がある。

なお，図一9には，30 波の地震動に対する設計 $3-C$ の最大層間相対変位の期待値の高さ方向の分布を実線 で, 平均値十標準偏差を点線で示す。変動係数には大差

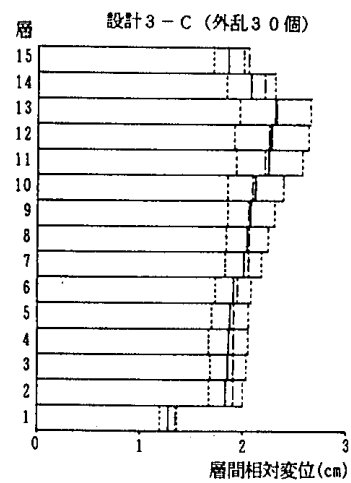

図一9 30 個の地震動に対する層間相対変位
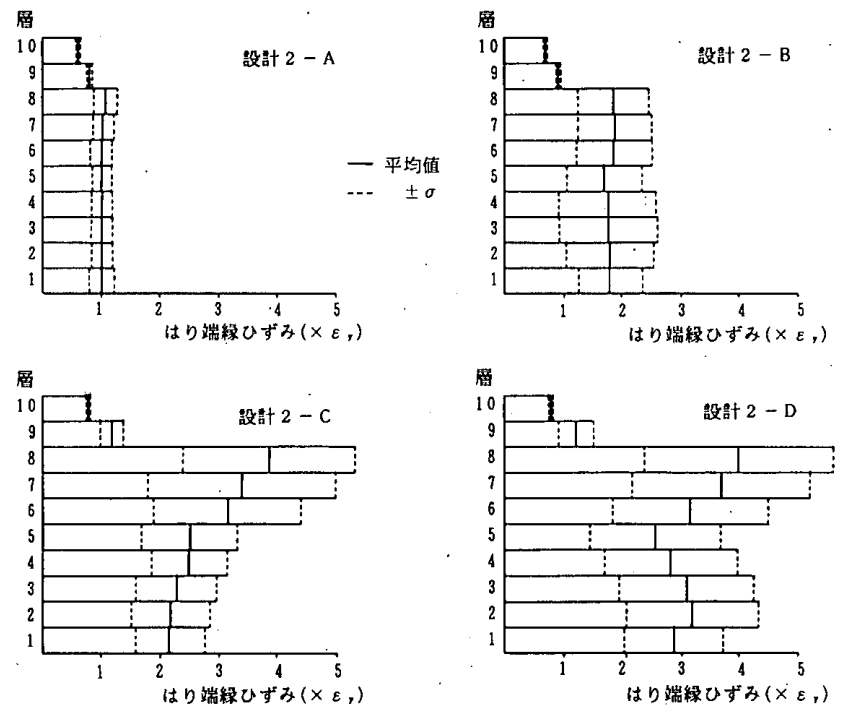

図一10 梁端縁ひずみ
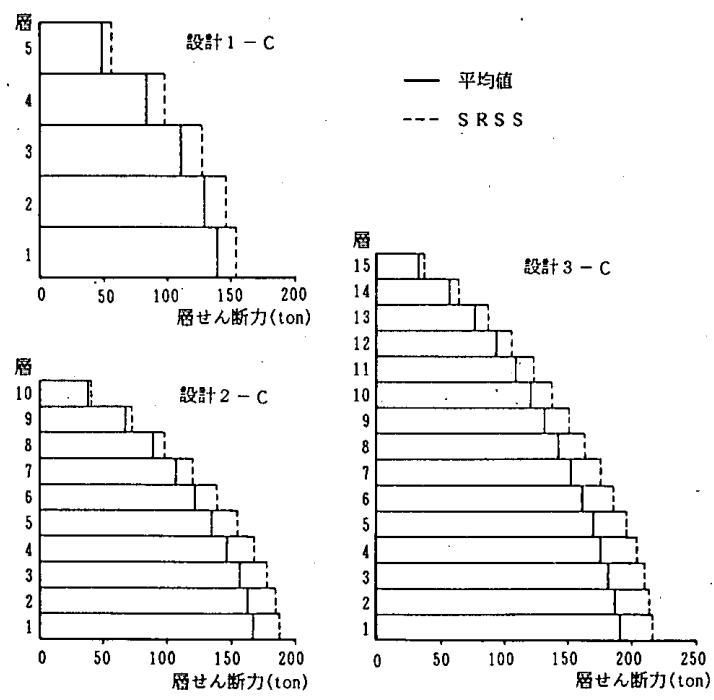

図一11 層せん断力

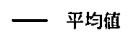

-.- SRS S

なく, 10 波の地震動に対する応答量でも応答量関係式 の誘導は可能であることがわかる。

〔最大ひずみ〕

10 層骨組の梁端縁ひずみの最大値の期待值を図一10 に実線で，期待値士標準偏差を点線で示す。

（1）図から明らかなとおり，ひずみの期待值の標準偏 差は大きく，塑性域でのひずみの值をクライテリア 2 に 

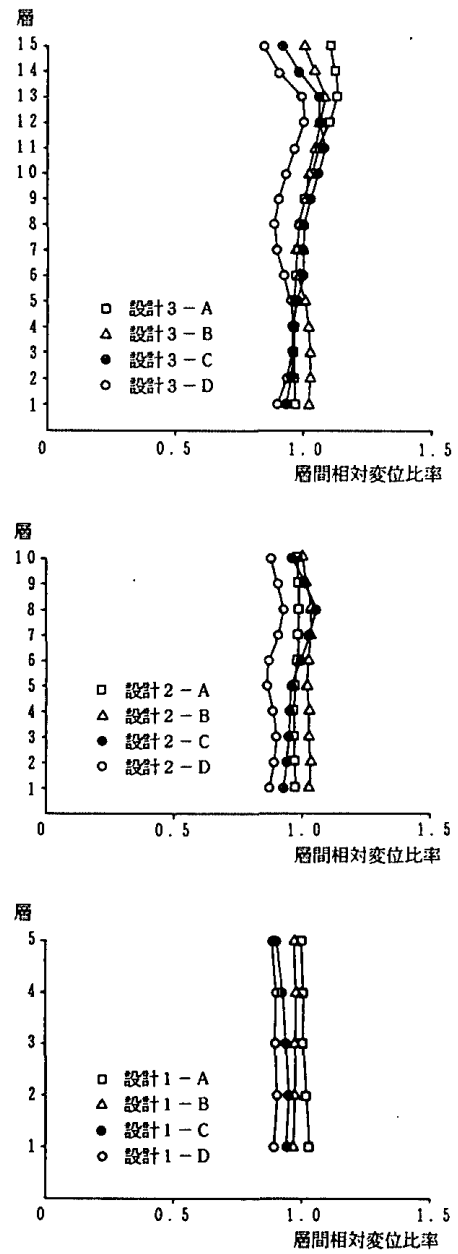

図一12 層間相対変位比率

採用することはできないことがわかる。

（2）一方，全地震動に対する全骨組の中間部の全梁の 最大ひずみ値の大部分は降伏棚領域を越えていない（ひ ずみ硬化域に達していない)。

[層せん断力]

レベル 2 骨組余裕率 0.75 の設計 3 の骨組の層せん断 力（柱の最大水平方向復元力）を図一11に夷線で示す。 また，図上に点線で弾性骨組としての SRSS 法予測値 を示す。

（1）弾塑性骨組の層せん断力と弾性骨組としての層せ ん断力の比率はどの層もほぼ一定であることがわかる。

4.3 弾塑性応答量関係式

前節で述べたように層方向分布が均質である応答量が 多いので，レベル 2 骨組余裕率をパラメータとして以下 の応答量の間の関係式が誘導できる。

〔層間相対変位比率]

図-12に，レベル 2 地震外乱に対する層ごとの層間 相対変位の応答量を弾性骨組としての SRSS 法予測値 で除した量をプロットした。この量を「層間相対変位比 率」と呼ぶ。なお，変動係数は前記の層間相対変位と同 じである。

層間相対変位比率は層方向にほぼ均一であることがわ

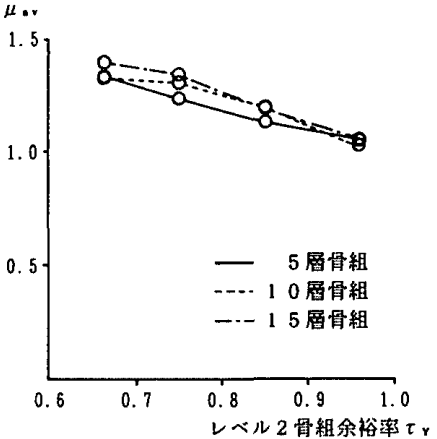

図一14 中層部平均塑性率

かる。そこで, 中層部の層間相対変位比率の層う向の平 均值（中層部層間相対変位比率 $\gamma$ ）を各骨組の層間相対 変位比率の代表值として採用し，レベル 2 骨組余裕率に 関してプロットしたのが図一13である。層数にかかわ りなく, レベル 2 骨組余裕率が小さいほど, 中層部層間 相対変位比率は小さくなることがわかる。

そのため，層間相対変位を SRSS 法予测値と同じで あるとして設計すれば安全側の設計が可能である。第 1 近似としては, 中層部層間相対変位比率 $\gamma$ は次式と見 なせばよい。

(中層部層間相対変位比率 1)

$$
\gamma=1.0
$$

また，第 2 近似としては，レベル 2 骨組余裕率 $\tau_{Y}$ に 関して中層部層間相対変位比率 $\gamma$ は以下のような関数 で表現できる。

(中層部層間相対変位比率 2)

$$
\gamma=1.0-0.71\left(\tau_{Y}-1\right)^{2}
$$

(29）式を採用した場合の変動係数は $15 \%$ 以下となる。 [層塑性率]

梁と柱で構成された骨組では，各層の弾性限層間相対 変位は骨組全体の変形モードによって異なる。ここでは, 弾性限レベル地震動下での降伏ひずみ指定層の各層の層 間相対変位を「弾性限層間相対変位 $\left.\delta_{y j}\right\rfloor$ と定義する。 これを基準にして層の「層塑性率 $\left.\left(\mu_{j}=\delta_{\max } / \delta_{y_{j}}\right)\right\rfloor を$ 計算することができる。

層間相対変位比率と同様に層塑性率は層方向にほぼ均 一であり, 標準偏差も層間相対変位と同様である。中層 部の塑性率の層方向の平均値（中層部平均塑性率 $\mu_{a v}$ ) を各骨組の中層部の塑性率の代表值として採用し，レベ ル 2 骨組余裕率に関してプロットしたのが図一14であ る。中層部平均塑性率もレベル 2 骨組余裕率 $\tau_{Y}$ に関し て, 以下のような (30) 式または (31) 式で表される関 係にあると見なすこともできる。

(中層部平均塑性率 1)

$$
\mu_{a v}=1 / \tau_{Y}
$$

(中層部平均塑性率 2)

$$
\mu_{a v}=\left\{1.0-0.71\left(\tau_{Y}-1\right)^{2}\right\} / \tau_{Y}
$$




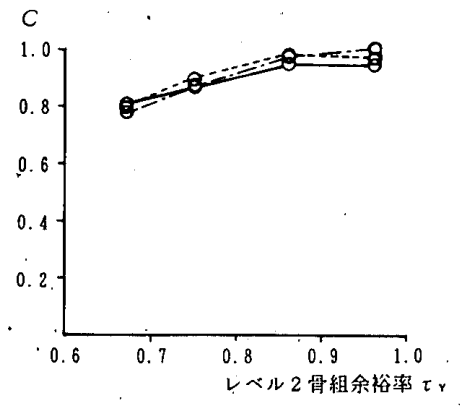

図一15 層せん断力比率

\section{〔層せん断力比率〕}

弾塑性骨組の層せん断力と弾性骨組としての層せん断 力の比率 (層せん断力比率) はどの層もほぼ一定である ので,全層の平均值でそれらを代表させることができる。 層せん断力比率をレベル 2 骨組余裕率に関してプロット したのが図一15である。これより，次式の関係式を誘 導することができる。

$$
C=1.0-1.9\left(\tau_{Y}-1\right)^{2} \cdots
$$

この関係式を設計時に利用することもできる。

\section{5. クライテリア 2 適合骨組と 2 段階応答制約骨組の設 計手順}

5.1 クライテリア 2 適合骨組の設計法

以下では，代表骨組モデルを対象とした詳細な応答量 関係式（(31)式）を用いるが，(30) 式を採用すれば, 種々 の部材中心線形状の骨組を対象とした場合にも，ほぼ条 件を満たし，若干安全側となる設計ができる。以下では

（7），（8）式で $\Delta=0.15 ， \sigma=0.2$ を採用しそのクラ イテリアに適合する骨組の設計法を示す。

（31）式は代表骨組モデルの層塑性率の予測式である が，この式を逆に使用することにより層塑性率を指定し た設計を以下のように行うことができる。

\section{〔設計手順 1]}

（ステップ1）（31）式において層塑性率を指定し， レベル 2 骨組余裕率を変数と見なして，採用すべきレ ベル 2 骨組余裕率を求める。

（ステップ2） 3 章で述べた均等塑性率骨組の作成法 を用いて，上記で求めたレベル 2 骨組余裕率を満たす 均等塑性率骨組の部材剛性, 断面形状を求める。

上記の設計手順には図一14より得られた関係曲線 （(31）式）を利用しているので，(7-a）式を十分満た 寸設計解が得られることがわかる。

\subsection{2 段階制約設計解誘導手順}

〔レベル 1 と 2 の地震動の応答スペクトルが相似形の場 合]

レベル 1 とレベル 2 の設計用地震動の応答スペクトル が相似形で，かつ，クライテリア1のひずみ指定值が均
等塑性率骨組の弾性限レベル地震動下でのひずみ分布と 同じ分布形状の場合には，いずれか一方の応答量に対す る制約条件が適合となり他方が許容となる骨組が設計解 となる。ここではレベル 2 設計用地震動はレベル 1 設計 用地震動の $\Gamma$ 倍とする。

クライテリア 2 適合骨組のレベル 2 骨組余裕率を(31) 式を使用して求める。弾性限レベル地震動に対してクラ イテリア 2 適合骨組は弾性限の応答を呈することにな る。

クライテリア 1 適合骨組はレベル 1 地震動に（降伏点 ひずみ最大ひずみの指定値）を乗じた地震動に対して 弾性限の応答を呈することになる。

ゆえに, 上記より両クライテリアに対する適合の判定 式が得られる。

(判定式 1]

$$
\Gamma \tau_{Y}<\varepsilon_{y} /\left[\operatorname{Max}\left\{\varepsilon_{B i \max }^{(1)}\right\}\right]
$$

上式が成立する場合にはクライテリア 2 よりクライテ リア 1 が活動的，不成立の時はクライテリア 1 よりクラ イテリア 2 が活動的である。設計手順は以下となる。

\section{〔設計手順 2〕}

（ステップ1）（31）式において層塑性率を指定し， 採用すべきレベル 2 骨組余裕率 $\tau_{r}$ を求める。

(ステップ2）（33）式が成立する場合には，クライ テリア 1 適合骨組の設計解を求める。この場合, レベ ル 2 地震外乱に対しては,

$$
\tau_{Y}=\left(\varepsilon_{y} / \Gamma\right) /\left[\operatorname{Max}\left\{\varepsilon_{B t \max )}^{(1)}\right\}\right]
$$

倍の余裕率を指定した均等塑性率骨組を設計したこと に相当する。

（ステップ 3）（33）式が不成立の場合は, クライテ リア 2 適合骨組設計すればよい。この場合にはレベル 1 地震外乱下での最大ひずみ値は指定値の

$$
\varepsilon_{y} / \Gamma \tau_{y}
$$

倍の大きさとなる。

〔レベル 1 と 2 の地震動の応答スペクトルが相似形でな い場合]

レベル 1 設計用地震動とレベル 2 設計用地震動の応答 スペクトルが相似形でないか，または，地震動が相似形 であってもクライテリア 1 のひずみ指定值が均等塑性率 骨組の弾性限レベル地震動下でのひずみ分布と同じ分布 形状でない場合には，いずれかのクライテリアに適合す る骨組が設計解になるとは限らない。この場合には均等 塑性率骨組群の中から両方のクライテリアに許容である 骨組を選定する必要がある。設計手順は以下となる。

\section{〔設計手順 3]}

（ステップ1）（31）式において層塑性率を指定し， 採用すべきレベル 2 骨組余裕率 $\tau_{Y}$ を求める。 


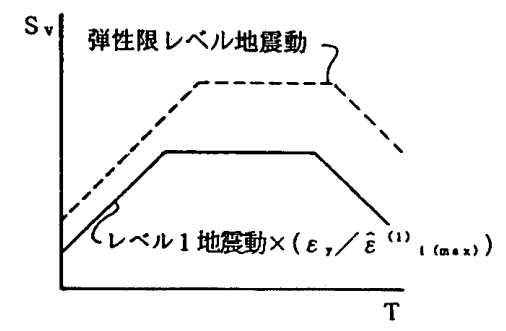

(a)
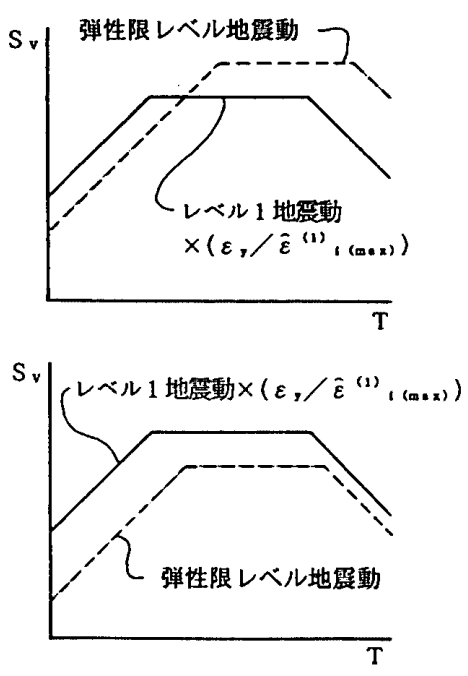

(b)

図一16 応答スペクトルの包絡関係

(ステップ 2) レベル 1 地震外乱に（降伏点ひずみ 最大ひずみの指定值）を乗じた地震動と $\tau_{Y}$ を用いて 決められる弾性限レベル地震動の両方の応答スペクト ルを作成する。

（ステップ3）弾性限レベル地震動の忘答スペクトル がレベル 1 応答スペクトルに（降伏点ひずみ ずみの指定値）を乗じた応答スペクトルを包絡する場 合（図一16-a) にはクライテリア 2 適合骨組が設計解 となる。

(ステップ4） ステップ 3 が満たされない場合（図一 16-b) には，まず，クライテリア 2 適合骨組のレベ ル 1 地震外乱に対する弾性応答量を求める。これらの 骨組のレベル 1 地震外乱に対する弾性応答量は SRSS 法により容易に計算できる。弾性応答量が指 定値以下となる場合にはクライテリア 2 適合骨組を採 用すればよい。

（ステップ 4）連続するレベル 2 骨組余裕率に対応す る均等塑性率骨組の集合の個々の要素は 3 章の手法で 容易に得られる。ステップ 3 が満たされない場合には， この骨組群から 1 個以上の部材のひずみが指定値と一 致する骨組を採用すればよい。

なお,クライテリア 1 適合骨組のレベル 2 地震外乱下 での挙動は必ずしも層塑性率が均一となるとは限らない が，2 個のレベルの地震動が相似形に近い場合には上記
の相似形の場合と同様の取り扱いをすることもできる。

\section{6. 記録地零動に対する骨組の挙動例}

5 章までの理論展開は設計用応答スペクトルに適合す る地震動に対する層塑性率制約設計法である。設計用地 震動として実地震動を採用する場合には，本設計法をそ のまま適用して層塑性率を指定值とする設計（クライテ リア 2 適合骨組の設計）を行うことはできないが, 文献 4）と同様に実地震動の応答スペクトルに外接する設計 用応答スペクトルに対して設計を行い, 層塑性率を指定 値以下とする設計（クライテリア 2 許容骨組の設計）を 行う方法も考えられる。

本章では，実地震動に対しても本設計骨組の最上層と 最下層を除く各層の層塑性率がほぼ均等となることおよ びクライテリア 2 許容骨組の設計法の可能性を例証する ために，エルセントロ地震動（NS 成分）および 1.58 倍に増幅したタフト地震動（EW 成分）に対する応答 解析を 3 個の骨組（レベル 2 骨組余裕率 0.75 の現実的 な部材剛性で構成された骨組）について行った。

エルセントロ地震動に対する 3 個の骨組の層塑性率の 高さ方向の分布を図一17 に示す。10層骨組の 1 次固有 周期に対応するエルセントロ地震動の速度応答スペクト ル值は 5 章で採用している設計用速度応答スペクトルの 最大值の約 1.2 倍となっている。そのため, 10 層骨組 では他の骨組より大きな層塑性率を示すが，よ゙の骨組に ついても中層部の層塑性率はほぼ均一の值となり, すべ て 2.0 以下の応答を示している。

タフト地震の 1.58 倍の地震動は, 主要な固有周期の 範囲 $(0.5$ 秒 -4.0 秒の範囲) で, 5 章で採用している 設計用速度応答スペクトルに対して内接する応答スペク トルを示す地震動となっている。この地震動に対する層 塑性率の高さ方向の分布を図一18に示す。層塑性率は 中層部でほぼ均一となり,かつ，1.0以下の弾性範囲内 に収まることがわかる。

これにより, 実地震動に対しても設計骨組の最上層と

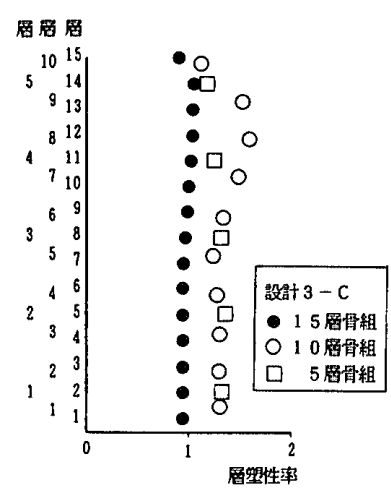

图一17 エルセントロ地震動 に対する層塑性率

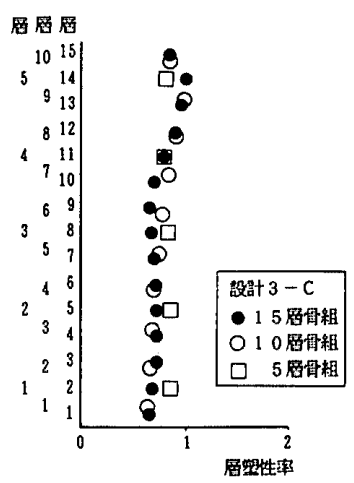

図一18 タフト地震動（倍率 1.58）に対する層塑 性率 
最下層を除く各層の層塑性率がほぼ均等となることおよ びクライテリア 2 許容骨組の設計に適用できる可能性が あることを例証した。

\section{7. 結 論}

本論文では代表骨組モデルを対象として設計用応答ス ペクトル適合地震動下での 2 段階応答制約設計法の理論 展開を行い，以下の成果を提示した。

（1）強震外乱（レベル 1 地震動）之激震外乱（レベル 2 地震動) の 2 個のレベルの地震動に対するそれぞれの 設計クライテリアを設定し，個々の制約条件下および 2 段階制約条件下での設計問題を述べた。これは通常の応 答解析法の逆問題である。

（2）上記の逆問題に対する新しい解法手順を提示し た。この解法には, その基礎的逆問題の解，すなわち, $\lceil 1$ 次固有周期と 1 次ひずみモード制御設計骨組の閉形 解」を利用しているので, 効率良く精度良い設計解が求 まる。

（3）梁降伏型均等スパン骨組などの特別な塑性率制約 骨組の場合には，実質的に弾性設計を行うことにより制 約条件を満足する骨組の設計ができることを示しだ。

ここでは代表骨組モデルを対象に設計解の誘導のス トーリーを展開したが，ここで得られる部材剛性や骨組 の強度は, 非線形性のレベルが層塑性率で 2 程度以内の 骨組の整合剛性や強度の標準値としての意義を有してい る。また, 各部材の強度, 剛性から断面形状まで同時に 求める理論であるので，設計解は内側梁，柱の初期設計 として直接使用することもできる。さらに，本論文は梁 降伏型骨組の設計法誘導の基本手順を提示したもので あって，より複雑な骨組（例えば立体骨組）の応答制御 理論や入力側の変動係数を考慮した理論へと展開するた めの基礎理論の提示と見なすこともできる。すでに立体 トラスのレベル 1 地震時の弾性応答ひずみ制約設計法も 提示している13)。そこでは線形理論により予測される応 答平均最大ひずみを制御しておけば，幾何学的非線形性 を考慮した応答ひずみもかなり良好な精度で制御できて いることを例証している。

なお,低層骨組の軸力を考慮した設計などに対しては, あらかじめ軸力によるひずみを考虑して曲げひずみの指 定値を操作することなどによりそのまま本設計法を淮用 することも可能である。

\section{謝 辞}

本論文のまとめに際して京都大学工学部助手 竹脇
出博士より有益な助言を得た。感謝の意を表する。

\section{参考文献}

1) 中村恒善, 小坂郁夫：平面建築骨組の指定設計ひすみみに 対する地震応答制約設計法, 日本建築学会構造系論文報 告集，第 430 号, pp. $79 \sim 89 ， 1991.12$

2) 中村恒善, 小坂郁夫：平面建築骨組の 1 次固有周期书上 び 1 次ひずみモード制御設計, 構造工学論文集, 第 35 号 B, pp. 9-17, 1989.3

3）例えば, T. Hisatoku and T. Kobori : “On the Optimum Aseismic Design Data for Multi-story Structures based on Elasto-plastic Earthquake Responses", Proc. 3rd Eur. Symp. Earthquake Eng. Sofia, pp. 435 445, 1970

4) Tsuneyoshi Nakamura and T. Yamane: "Optimum Design and Earthquake-response Constrained Design of Elastic Shear Buildings", Earthquake Engineering and Structural Dynamics, Vol.14, pp. 797 815, 1986

5) I. Kosaka and Tsuneyoshi Nakamura: "Inelastic Response Constrained Design of Shear Buildings via Elastic Response Constrained Design", Proc. of 9WCEE, 5, pp. 965 970, 1989

6) 石丸辰治：塑性率制御法 (その 1 , その 2), 日本建築学 会論文報告集, 第 232 号, pp. 17 25，1975.6，第 233 号, pp. $61 \sim 68,1975.7$

7）藤原悌三，秋元理仁：地盤特性を考虑した梁降伏型架構 の適正設計, 京都大学防災研究所年報, 第 34 号 B-1, pp. 87 99, 1991. 4

8）秋山 宏：建築物の耐震極限設計 (第 2 版), 東京大学出 版会, 1987

9) Tsuneyoshi Nakamura and I. Takewaki: "Ductility Design via Optimum Design of Nonlinear Elastic Frames", Journal of Structural Engineering, ASCE, Vol.115, No. 3, pp. 608 625, 1989

10) Newmark, N. M. and W. J. Hall : "Earthquake Spectra and Design", Earthquake Engineering Research Institute, Berkeley, 1982

11）中村恒善, 鎌形修一, 小坂郁夫：非定常履歴単軸構成法 則とその部材解析への適用, 日本建築学会論文報告集, 第 300 号, pp. $11 \sim 18$, 1981.2, 第 301 号, pp. $9 \sim 15$, 1981.3

12) D. A. Gasparini and E.H. Vanmarcke: "A Computer Program Distributed by NISEE/Computer Applications, Massachusetts Inst. of Tech., Cambridge, MA, 1976

13) Tsuneyoshi Nakamura and Makoto Ohsaki : "Sequential Generator of Earthquake-response Constrained Trusses for Design Strain Ranges", Computer \& Structures Vol. 33, No. 6, pp. 1403 1416, 1989

(1992 年 2 月 10 日原稿受理, 1992 年 6 月 12 日採用決定） 